\title{
A NEW SPECIES OF PSEUDOXANDRA (ANNONACEAE)
}

\author{
PAUL J.M. MAAS \& LUBBERT Y.TH. WESTRA \\ Nationaal Herbarium Nederland, Utrecht University branch, W.C. van Unnikgebouw, \\ Heidelberglaan 2, 3584 CS Utrecht, The Netherlands
}

\begin{abstract}
SUMMARY
A new species, as an addition to the revision of the genus Pseudoxandra by Maas \& Westra (2003), is described.
\end{abstract}

Key words: Annonaceae, Pseudoxandra, taxonomy.

\section{INTRODUCTION}

In a recent revision of Pseudoxandra (Maas \& Westra, 2003), 2 vegetative collections of Colombia were included as Pseudoxandra spec. A. During recent fieldwork in Peru fertile (fruiting) material of the same species was collected, allowing us to describe this hitherto unnamed species now.

Pseudoxandra angustifolia Maas, spec. nov. - Fig. 1; Map 1

Species foliis angustissimis distincta. - Typus: Pirie et al. 139 (holo U; iso HAO, HUT, K, MO, NY, USM), Peru, San Martín, km 20 of road from Tarapoto to Yurimaguas, Estación 'Biodiversidad'.

Pseudoxandra spec. A, Murillo-A. \& D. Restrepo (2000) 143, f. 46; Maas \& Westra, Blumea 48 (2003) 255.

Tree 6-15 m tall, diam. unknown; young twigs glabrous. Leaves: petiole $2-3 \mathrm{~mm}$ long, $0.5-0.6 \mathrm{~mm}$ diam.; lamina narrowly elliptic, $7-12$ by $0.7-1.7 \mathrm{~cm}$ (leaf index 5-9), symmetrical or slightly asymmetrical, chartaceous, smooth (not verruculose), dull, black to dark brown above and pale brown below in sicco, glabrous above, sparsely covered along the primary vein with appressed, whitish hairs to $1 \mathrm{~mm}$ long below, very soon becoming glabrous, base acute to obtuse, with or without 2 angular to toothlike projections on either side, apex gradually and long-acuminate (acumen 10-20 mm long), the tip itself obtuse, secondary veins very indistinct, straight, 15-20 (hardly countable) on either side of primary vein, flat above, angles with primary vein $75-80^{\circ}$, smallest distance of marginal vein from margin $0.1-0.3 \mathrm{~mm}$. Inflorescences 1-flowered, produced from leafless branches; fruiting peduncles c. $1 \mathrm{~mm}$ long, 2-3 mm diam., glabrous; bracts 1 or 2, depressed ovate, c. $1 \mathrm{~mm}$ long, outer side densely covered with appressed, whitish hairs; fruiting pedicels c. $2 \mathrm{~mm}$ long, 2-3 mm diam., glabrous; sepals depressed ovate, $1-1.5$ by $3 \mathrm{~mm}$, the outer side densely covered with appressed, whitish hairs; petals, stamens, and carpels not seen. Monocarps 1-10, green 

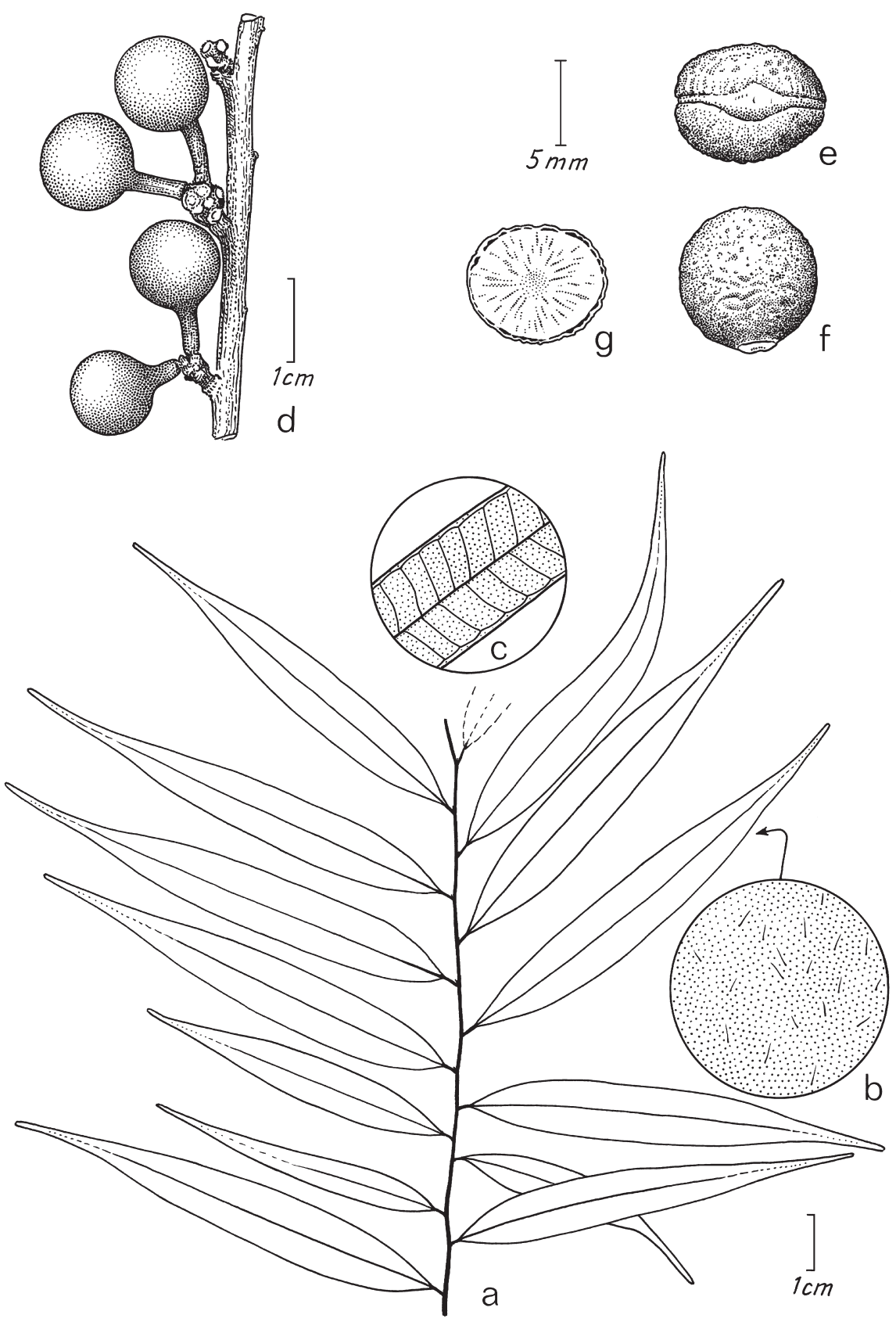

Fig. 1. Pseudoxandra angustifolia Maas. a. Leafy branch; b. indument on lower side of leaf; c. leaf venation; d. fruiting branch; e. seed in polar view; f. seed in equatorial view; g. seed in transverse section (all: Pirie et al. 139, U). 


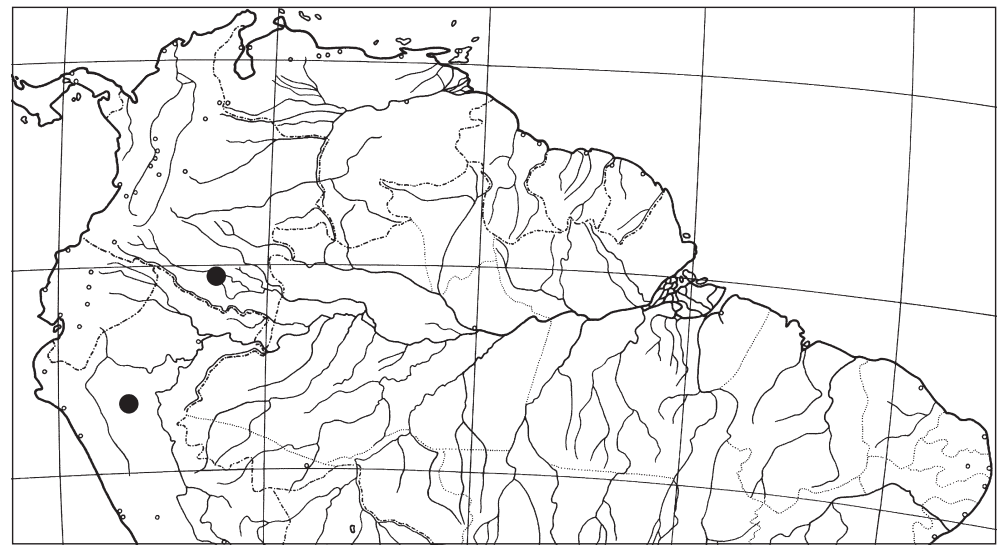

Map 1. Distribution of Pseudoxandra angustifolia Maas.

in vivo, black in sicco, globose, $9-10 \mathrm{~mm}$ diam., apex with an eccentric apicle (apicle c. $0.5 \mathrm{~mm}$ long), wall $0.8-1 \mathrm{~mm}$ thick, stipes $4-10$ by $1-2 \mathrm{~mm}$; fruiting receptacle globose to depressed ovoid, 3-5 mm diameter. Seeds transversely ellipsoid, 9-10 by 6-7 mm, pale brown.

Distribution - Amazonian Peru and Colombia.

Habitat \& Ecology - In non-inundated forest, on white sands (Peru) or on clayey soil (Colombia). At low elevations. Fruiting in December.

Vernacular names - Colombia: Carguero, 'J+rida iviniai' (Huitoto; see Sánchez Sáenz, 1997).

Note - In our recent revision of Pseudoxandra (Maas \& Westra, 2003) 2 vegetative collections of Colombia were included as Pseudoxandra spec. A. It was also cited as "Pseudoxandra sp. A" in Murillo-A. \& Restrepo (2000). During a recent expedition in Peru the Utrecht PhD student M. Pirie, accompanied by T. Diaz F. and M. Zapata C. from Peru, and two Dutch graduate students, namely Mrs. M. Botermans and Mr. R. van Velzen, collected fruiting material of a narrow-leaved species of Pseudoxandra at the field station 'Biodiversidad' of the Universidad Nacional de San Martín, near Tarapoto. It soon became evident after closer examination that this material belonged to the same species as Pseudoxandra spec. A, and that it was an undescribed species. Because of its characteristic narrow leaves (unique for the genus) it is named P. angustifolia. Due to the incompleteness of the material (only fruiting material present), its relationship is still unknown.

Other specimens examined:

Colombia. Caquetá: Araracuara, trail to Río Yarí, Murillo-A. \& Román O. 582, 616 (U).

\section{ACKNOWLEDGEMENTS}

The main collector of the type material of this new species, Michael Pirie, is very much indebted to the staff of the Universidad de San Martín, Peru, particularly J.D. Vásquez and M.D. León. They provided a field guide, a bus for one day, and let him stay at their camp. The two authors are indebted to Mr. Hendrik Rypkema who prepared the drawing and the distribution map. 


\section{REFERENCES}

Maas, P.J.M. \& L.Y.Th. Westra. 2003. Revision of the Neotropical genus Pseudoxandra (Annonaceae). Blumea 48: 201-259.

Murillo-A., J. \& D. Restrepo. 2000. Las Anonáceas de la region de Araracuara. Estudios en la Amazonia colombiana XX: 143. Tropenbos Colombia.

Sánchez Sáenz, M. 1997. Catálogo preliminar comentado de la flora de Medio Caquetá. Estudios en la Amazonia colombiana XII: 40. Tropenbos Colombia. 